\title{
Arthrodesis of the Foot or Ankle in Adult Patients with Congenital Clubfoot
}

\author{
Thompson Zhuang ${ }^{1}$, Ghida El-Banna ${ }^{1}$, Steve Frick ${ }^{2}$ \\ 1. Orthopaedic Surgery, Stanford University, Stanford, USA 2. Orthopaedics, Stanford University, Stanford, USA
}

Corresponding author: Thompson Zhuang, tzhuang@stanford.edu

\begin{abstract}
\section{Background}

Although clubfoot that was corrected in childhood rarely recurs in adulthood, persistent deformities or arthritic pain may require further treatment during adulthood. Little evidence exists on the operative procedures utilized in adult clubfoot patients, who were previously treated for congenital clubfoot in childhood, for residual or recurrent deformity or pain.
\end{abstract}

\section{Objective}

The objective of this study is to characterize the types and frequencies of procedures utilized in adult clubfoot patients, who were previously treated for congenital clubfoot in childhood.

\section{Methods}

A two-pronged approach was employed to describe the operative procedures used in adult clubfoot patients. First, a literature review of all reported cases of operative treatment in adult clubfoot patients who were previously treated in childhood was performed. Second, an analysis of the operative treatments used in adult patients with a diagnosis of congenital clubfoot was conducted using a large, administrative claims database.

\section{Results}

In the literature review, arthrodesis was the most cited operative treatment and reported in four out of the eight studies included. Osteotomies were also reported in the literature. In the database analysis, 94 hindfoot arthrodesis procedures were identified in 73 patients, out of 1,198 adult patients in the database with a diagnosis of congenital clubfoot. Sixty-two patients out of 1,198 adult clubfoot patients received osteotomies. An insufficient number of total ankle arthroplasties were reported for further analysis.

\section{Conclusions}

Received 09/25/2019

Review began 09/26/2019 Review ended 12/27/2019 Published 12/29/2019

\section{() Copyright 2019}

Zhuang et al. This is an open access article distributed under the terms of the Creative Commons Attribution License CC-BY 3.0., which permits unrestricted use, distribution, and reproduction in any medium, provided the original author and source are credited.

Operative treatment in adult clubfoot patients who were treated for congenital clubfoot in childhood includes hindfoot arthrodesis and osteotomy procedures. Total ankle arthroplasty has not been reported in the literature for these patients.

Categories: Orthopedics

Keywords: arthrodesis, congenital clubfoot, osteotomy, pediatric orthopaedics

\section{Introduction}

Congenital clubfoot, also known as congenital talipes equinovarus, is a common birth defect with a prevalence of approximately one in 1,000 live births [1]. Clubfoot that was formerly treated in childhood rarely recurs in adulthood, although persistent deformities or arthritic pain may need treatment in adulthood [2]. Nevertheless, little information exists on clubfoot treatment in adults. Several case studies have described salvage techniques including double and triple arthrodesis procedures for treating neglected clubfoot and late recurring idiopathic clubfoot in the adult patient [2-5]. However, for patients with clubfoot treated in childhood, the need for further surgery in adulthood is not well described in the literature. Parents and patients often have questions about the possible need for surgery as adults for residual or recurrent deformity, or for pain, but little is known about the incidence, indications, or operations used to treat adult clubfoot patients. In addition, medicolegal cases involving young clubfoot patients often calculate estimated lifetime healthcare costs and include future operations such as triple arthrodesis or total ankle replacement when preparing a life care plan cost assessment. For example, lifetime cost assessments, including relevant costs borne in adulthood, for other childhood conditions with medicolegal ramifications have been performed for child maltreatment, hypoxic-ischemic birth injury, and childhood obesity [6-11].

This study evaluates operative treatments used in adult patients with congenital clubfoot treated in 
childhood by employing two approaches: 1) a thorough literature review of existing cases and 2) an analysis of adult clubfoot patients undergoing ankle or foot surgery in a large administrative claims database.

\section{Materials And Methods \\ Literature review methods}

A literature search was conducted to capture all articles pertaining to patients with congenital clubfoot, who were treated with either nonoperative or operative methods during infancy and later received operative treatment during adulthood to relieve pain or improve foot position. English-language articles and all years up to September 2019 were included. The search strings used are available in Supplementary Information. The PubMed and Embase databases were searched, which returned 285 and 128 articles in PubMed and Embase, respectively. There were a total of 374 articles after excluding duplicates. Screening abstracts to determine whether the article addressed the operative treatment of previously treated clubfoot in adults led to the exclusion of 353 articles. Twenty-one full-text articles were assessed for eligibility. Included studies reported patients who 1) were diagnosed with congenital, idiopathic clubfoot in the first months after birth, 2) treated for clubfoot during childhood either surgically or non-surgically, and 3) underwent surgical procedure(s) as adults to correct recurrent, residual, or overcorrected clubfoot and foot position or to alleviate foot pain. Only eight articles met these inclusion criteria and were included in the qualitative analysis (Figure 1).

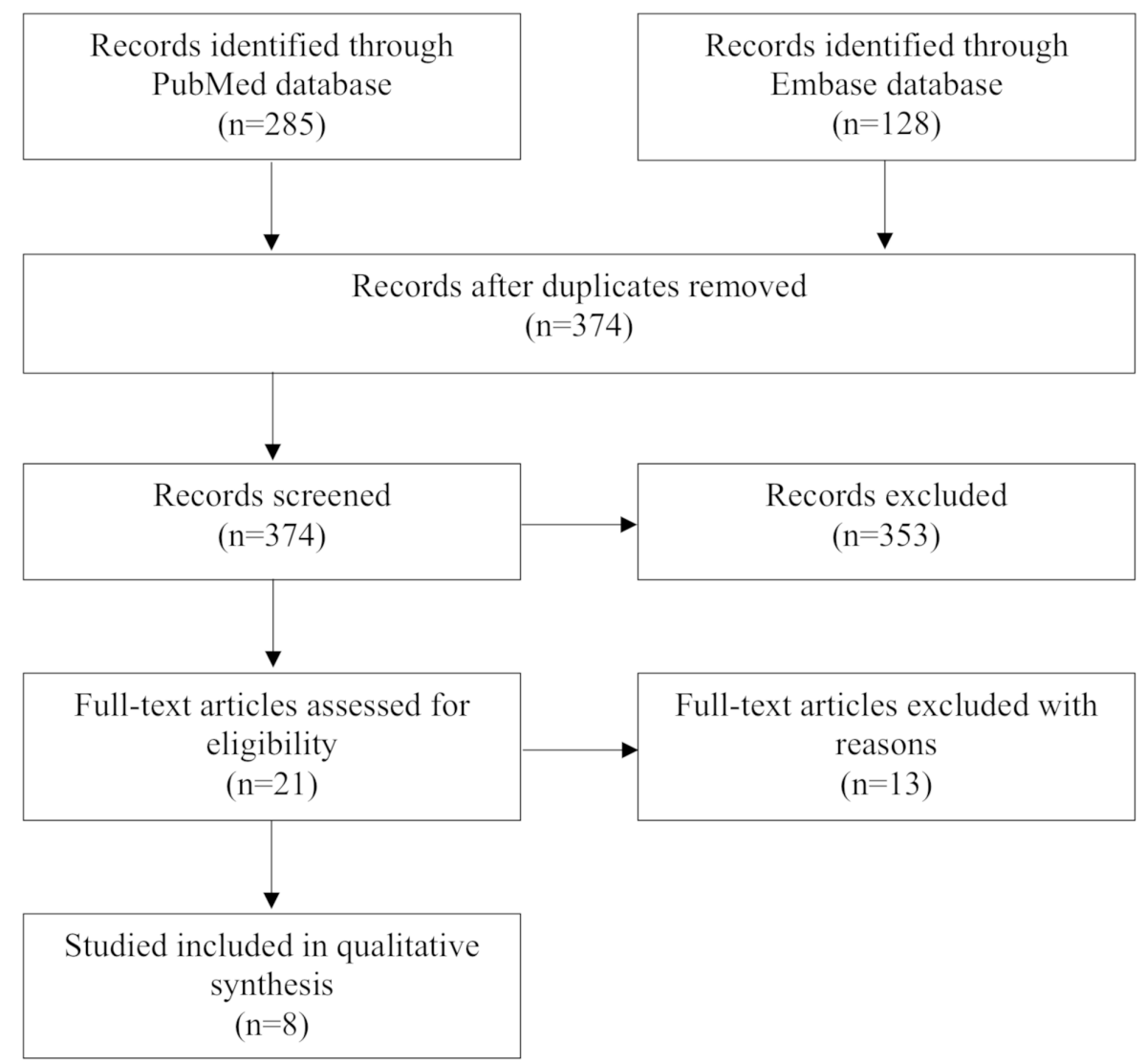

FIGURE 1: Literature review scheme

\section{Database analysis methods}

Humana's administrative claims database was analyzed using commercially available PearlDiver software (PearlDiver, Inc.; Colorado Springs, CO). This database comprises patient records from over 25 million members from 2007 to 2017 and includes payer data from both commercial and Medicare Advantage plans. Claims data include dates, diagnoses, procedures, and patient demographics, such as geographic location as defined by the United States Census Bureau. The database contains claims from diverse medical and surgical specialties, including podiatry. This database has been previously used in orthopedic research and its characteristics have been described elsewhere [12]. Because all data were de-identified and anonymous, institutional review board (IRB) approval was not required.

All patient records associated with a diagnosis of congenital talipes equinovarus (congenital clubfoot) were 
identified using International Classification of Diseases, Ninth or Tenth Revision (ICD-9 or ICD-10) diagnosis codes and included in the analysis (Table 1 ). Because the database only codes age in five-year buckets, adults were defined as patients at or over 20 years old. All patients under 20 years of age or with a diagnosis of acquired clubfoot were excluded. Demographic information on all patients diagnosed with congenital clubfoot was obtained, including the age, region, and service location associated with each claim. Using Boolean-type search functions, clubfoot patients who underwent mid-tarsal joint arthrodesis, subtalar arthrodesis, ankle arthrodesis, triple arthrodesis, total ankle arthroplasty, or osteotomy procedures were identified using their respective Current Procedural Terminology (CPT) codes (Table 1). Count data are reported for each of the procedures. As they have lower costs and lower morbidity and are relatively infrequent, we did not include soft tissue procedures in our database analysis.

Diagnosis or Procedure
Congenital clubfoot
Acquired clubfoot
Mid-tarsal joint arthrodes
Anktalar arthrodesis
Triple arthrodesis
Total ankle arthroplasty
Osteotomy

\section{Diagnosis or Procedure}

\section{ICD-9/10 or CPT Code}

ICD-9-D-75451, ICD-10-D-Q660

ICD-9-D-73671, ICD-10-D-M21541, ICD-10-D-M21542, ICD-10-D-M21549

CPT-28740

CPT-28725

CPT-27870, СРT-29899

CPT-28715

CPT-27700, CPT-27702

CPT-28300, CPT-28302, CPT-28304, CPT-28305, CPT-28306, CPT-28307, CPT-28308, CPT-28309

\section{TABLE 1: Definitions of Diagnosis and Procedural Codes used}

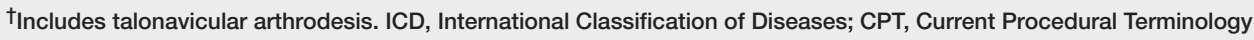

\section{Results}

\section{Literature review}

The studies included in this review reported symptomatic adult clubfoot patients with pain, difficulty walking, inability to wear conventional shoes, flatfoot, ossification of the Achilles tendon, and calf muscle hypotrophy. A summary is provided in Table 2 . Arthrodesis was the most cited operative treatment (in four out of eight studies). Blitz et al. reported a case of a 22 -year-old female with bilateral clubfeet treated with a posteromedial release in childhood [13]. The patient presented with difficulty walking, disfigured feet, and right rearfoot pain. The interposition of the flexor hallucis longus tendon was found intraoperatively, and the patient was successfully treated with triple arthrodesis [13]. Eberhardt et al. presented a series of 21 patients between the ages of 11 and 26 years [14]. These patients presented with flatfeet and pain due to extensive clubfoot surgery in childhood. Six feet were treated with arthrodesis and 19 feet were treated with tarsal osteotomies. Overall, the range of motion did not improve, and $81 \%$ of patients were satisfied with the surgery outcomes [14]. Ramseier et al. reported a series of seven patients with unilateral clubfoot in the age group of 18 to 45 years [2]. Childhood treatments included casting, soft tissue release, Achilles tendon lengthening, midfoot arthrodesis, medial release, dorsomedial release, and plantar fascia lengthenings. All were treated with triple arthrodesis. They reported satisfactory outcomes, despite several complications such as residual symptoms, degenerative changes at the ankle in $57 \%$ of the patients, and increased ankle arthritis in $67 \%$ of the patients. Pain was reduced but not completely alleviated, and ankle motion remained unchanged [2]. Wei et al. reported 16 patients in the age group of 4 to 20 years who received clubfoot release during childhood [15]. Individual patient data were not reported; thus, the number of patients who were at least 18 years old could not be determined. All patients underwent talonavicular arthrodesis for residual midfoot deformities. In addition to arthrodesis, lateral column shortening with a calcaneal wedge osteotomy was performed in eight patients, and two patients required a bone graft to fill a residual gap at the talonavicular fusion site. Fourteen patients were completely satisfied with surgery outcomes, and two patients were partially satisfied. All patients reported pain relief and correction of residual deformities, as reflected in the improvement of the talus-first metatarsal angle [15].

\begin{tabular}{|c|c|c|c|c|c|c|}
\hline $\begin{array}{l}\text { Author(s) } \\
\text { \& Year }\end{array}$ & Study Type & $\begin{array}{l}\text { Number } \\
\text { of } \\
\text { Patient(s) }\end{array}$ & $\begin{array}{l}\text { Childhood Treatment(s) } \\
\text { (Chronologically) }\end{array}$ & $\begin{array}{l}\text { Clubtoot-related } \\
\text { Problem in } \\
\text { Adulthood }\end{array}$ & $\begin{array}{l}\text { Adulthood } \\
\text { Treatment(s) }\end{array}$ & $\begin{array}{l}\text { Outcomes of } \\
\text { Adulthood } \\
\text { Treatment(s) }\end{array}$ \\
\hline
\end{tabular}




\section{Cureus}

\begin{tabular}{|c|c|c|c|c|c|c|}
\hline $\begin{array}{l}\text { Blitz et al. } \\
\text { (2008) }\end{array}$ & Case Report & 1 & Posteromedial release & $\begin{array}{l}\text { Interposition of } \\
\text { the flexor hallucis } \\
\text { longus tendon } \\
\text { through the } \\
\text { subtalar joint }\end{array}$ & Triple arthrodesis & $\begin{array}{l}\text { Satisfactory without } \\
\text { complications }\end{array}$ \\
\hline $\begin{array}{l}\text { Eberhardt } \\
\text { et al. } \\
(2018)\end{array}$ & Prospective & $21^{\dagger}$ & $\begin{array}{l}\text { Posteromedial release or peritalar } \\
\text { release }\end{array}$ & $\begin{array}{l}\text { Hindfoot } \\
\text { deformities: one } \\
\text { rotational valgus, } \\
14 \text { mild hinge } \\
\text { valgus, seven } \\
\text { translatory } \\
\text { valgus, and three } \\
\text { cases with a } \\
\text { combination of a } \\
\text { rotational and a } \\
\text { mild hinge valgus }\end{array}$ & $\begin{array}{l}\text { Tarsal osteotomies } \\
\text { in } 19 \text { patients, } \\
\text { arthrodesis in six } \\
\text { patients, and all } \\
\text { flatfeet with } \\
\text { translator valgus that } \\
\text { were initially treated } \\
\text { with a tarsal } \\
\text { osteotomy required } \\
\text { further arthrodesis }\end{array}$ & $\begin{array}{l}\text { No improvement in } \\
\text { range of motion, } 81 \% \\
\text { satisfied with surgery } \\
\text { outcomes }\end{array}$ \\
\hline $\begin{array}{l}\text { Ramseier } \\
\text { et al. } \\
(2007)\end{array}$ & Prospective & 7 & $\begin{array}{l}\text { (1) Casting, soft-tissue release, } \\
\text { and Achilles tendon lengthening in } \\
\text { three cases, (2) Casting, soft- } \\
\text { tissue release, and Achilles } \\
\text { tendon lengthening; Chopart } \\
\text { arthrodesis in one case, (3) } \\
\text { Casting, Achilles tendon } \\
\text { lengthening, medial release, } \\
\text { dorsomedial release, Steindler } \\
\text { procedure in two cases, (4) } \\
\text { Casting, soft-tissue release in one } \\
\text { case }\end{array}$ & $\begin{array}{l}\text { Late recurrent } \\
\text { idiopathic } \\
\text { clubfoot } \\
\text { deformity }\end{array}$ & Triple arthrodesis & $\begin{array}{l}\text { Satisfactory outcomes } \\
\text { but degenerative } \\
\text { changes at the ankle in } \\
57 \% \text { of patients, } \\
\text { increased ankle arthritis } \\
\text { in } 67 \% \text { of patients, pain } \\
\text { reduction but not } \\
\text { complete alleviation, } \\
\text { and unchanged ankle } \\
\text { motion }\end{array}$ \\
\hline $\begin{array}{l}\text { Wei et al. } \\
(2000)\end{array}$ & Retrospective & $16^{\ddagger}$ & Clubfoot release & $\begin{array}{l}\text { (1) Triangular } \\
\text { navicular, (2) } \\
\text { dorsal-lateral } \\
\text { subluxation of } \\
\text { the talonavicular } \\
\text { joint with a } \\
\text { secondary } \\
\text { forefoot } \\
\text { cavovarus } \\
\text { deformity and (3) } \\
\text { degenerative } \\
\text { changes of the } \\
\text { talonavicular joint }\end{array}$ & $\begin{array}{l}\text { (1) Talonavicular } \\
\text { arthrodesis, (2) } \\
\text { additional lateral } \\
\text { column shortening } \\
\text { with a calcaneal } \\
\text { wedge osteotomy in } \\
7 \text { patients, (3) } \\
\text { additional bone graft } \\
\text { to fill a residual gap } \\
\text { at the talonavicular } \\
\text { fusion site in two } \\
\text { patients }\end{array}$ & $\begin{array}{l}14 \text { patients completely } \\
\text { satisfied and two } \\
\text { patients partially } \\
\text { satisfied due to } \\
\text { navicular-cuneiform } \\
\text { osteoarthritis in both } \\
\text { feet three years after } \\
\text { surgery, pain relief, } \\
\text { correction of the } \\
\text { residual deformities, } \\
\text { improved talus-first } \\
\text { metatarsal angle }\end{array}$ \\
\hline $\begin{array}{l}\text { Andjelkov } \\
\text { et al. } \\
\text { (2018) }\end{array}$ & Prospective & 72 & Achilles tenotomy & $\begin{array}{l}\text { Undeveloped } \\
\text { calves }\end{array}$ & Calf silicone implant & $\begin{array}{l}\text { Excellent results with } \\
\text { low complication rates }\end{array}$ \\
\hline $\begin{array}{l}\text { Knupp et } \\
\text { al. (2012) }\end{array}$ & Prospective & 14 & $\begin{array}{l}\text { (1) Serial casting and manipulation } \\
\text { in the first months after birth (2) } \\
\text { posteromedial release and release } \\
\text { of the talocalcaneal interosseous } \\
\text { ligament after relapse }\end{array}$ & $\begin{array}{l}\text { Ankle } \\
\text { impingement in } \\
\text { patients with } \\
\text { overcorrected } \\
\text { clubfoot } \\
\text { deformity }\end{array}$ & $\begin{array}{l}\text { Supramalleolar tibial } \\
\text { osteotomy and } \\
\text { additional calcaneal } \\
\text { osteotomy or plantar } \\
\text { flexion osteotomy in } \\
\text { same cases }\end{array}$ & $\begin{array}{l}\text { Low risk of } \\
\text { complications, } \\
\text { significant pain } \\
\text { reduction, and } \\
\text { increased ankle motion }\end{array}$ \\
\hline $\begin{array}{l}\text { Majeed et } \\
\text { al. (2015) }\end{array}$ & Case Report & 1 & Achilles tendon lengthening & $\begin{array}{l}\text { Multiple } \\
\text { ossifications of } \\
\text { the Achilles } \\
\text { tendon }\end{array}$ & $\begin{array}{l}\text { Surgical excision of } \\
\text { bony lumps }\end{array}$ & $\begin{array}{l}\text { Satisfactory without } \\
\text { complications }\end{array}$ \\
\hline $\begin{array}{l}\text { Walling } \\
\text { (2008) }\end{array}$ & Case Report & 1 & $\begin{array}{l}\text { Serial casting in the first two years } \\
\text { of life }\end{array}$ & $\begin{array}{l}\text { Ankle motion of } \\
\text { the equinus } \\
\text { position with } \\
\text { minus } 10^{\circ} \text { of } \\
\text { neutral and an } \\
\text { additional } 15^{\circ} \text { of } \\
\text { plantar flexion, }\end{array}$ & $\begin{array}{l}\text { (1) Open tendo- } \\
\text { Achilles and flexor } \\
\text { digitorum longus } \\
\text { lengthening, (2) } \\
\text { midfoot capsular } \\
\text { releases, (3) } \\
\text { calcaneal and first }\end{array}$ & $\begin{array}{l}\text { Plantigrade foot with } 7^{\circ} \\
\text { ankle dorsiflexion and } \\
\text { correction of the } \\
\text { hindfoot varus }\end{array}$ \\
\hline
\end{tabular}




\section{Cureus}

\begin{tabular}{|l|l|} 
hindfoot in varus & metatarsal \\
and midfoot & dorsiflexion \\
abduction & osteotomies \\
\hline
\end{tabular}

\section{TABLE 2: Summary and characteristics of studies included in the literature review}

${ }^{\dagger}$ Age range is 11 to 26 years old, and individual patient information was not available.

${ }^{\ddagger}$ Age range is 4 to 20 years old, and individual patient information was not available.

[2], [13-19]

Besides arthrodesis, other reported procedures included calf silicone implants, supra-malleolar osteotomy, excision of bony lumps, and tendon lengthening. Andjelkov et al. reported 71 patients with unilateral calf hypoplasia and one patient with bilateral hypoplasia [16]. All had a history of Achilles tenotomy after clubfoot relapse during childhood. These patients presented with calf atrophy, decreased foot size, limited mobility, and decreased tibial length. All patients underwent calf enhancement surgery and reported gratifying aesthetic results [16]. Knupp et al. reported 14 patients in the age group of 19 to 66 years treated with serial manipulations and casting in the first months after birth [17]. All 14 patients had clubfoot relapse that was treated with posteromedial release and a release of the talocalcaneal interosseous ligament during childhood. As adults, these patients presented with calcaneofibular impingement either with or without anterior ankle impingement and painful restriction of the ankle joint. A supra-malleolar tibial osteotomy was performed in all patients. Five patients also had additional calcaneal osteotomy and another five patients had a plantar-flexion osteotomy. All patients reported improved ankle motion, reduced pain, and walking in normal shoes [17]. Majeed et al. reported a case of a 24-year-old male with a history of bilateral clubfeet treated with Achilles tendon lengthening at the age of three [18]. The patient presented to the clinic with several swellings over his right Achilles tendon and was found to have intra-tendinous ossifications. Bony lumps were surgically removed, which resulted in pain reduction [18]. Finally, Walling et al. reported a case of an 18-year-old female with a history of unilateral clubfoot treated with serial casting in the first two years of life [19]. The patient presented to the clinic with pain, difficulty walking, and inability to wear conventional shoes. She was treated with open Achilles tendon and flexor digitorum longus lengthening, fractional posterior tibial lengthening, midfoot capsular releases, and calcaneal and first metatarsal osteotomies. She reported satisfactory outcomes of plantigrade foot and corrected hindfoot varus [19].

\section{Database analysis}

From a total population of $25,025,699$ patients in the database, 2,056 patients $(0.008 \%)$ received evaluation and treatment associated with congenital clubfoot. Of these congenital clubfoot patients, $52 \%$ were male and $48 \%$ were female. The age at which these patients received any treatment associated with congenital clubfoot was further characterized (Table 3).

\begin{tabular}{|c|c|c|}
\hline Characteristic & All Patients, $\mathbf{n}$ & Patients $\geq 20$ years old, $n$ \\
\hline Total Patients & 2,056 & 1,198 \\
\hline \multicolumn{3}{|l|}{ Sex } \\
\hline Male & $1,062(52 \%)$ & $530(44 \%)$ \\
\hline Female & 994 (48\%) & $668(56 \%)$ \\
\hline \multicolumn{3}{|l|}{$\mathrm{Age}^{\dagger}$ (years) } \\
\hline 0 to 4 & 597 & \\
\hline 5 to 9 & 186 & \\
\hline 10 to 14 & 179 & \\
\hline 15 to 19 & 100 & \\
\hline 20 to 24 & 31 & \\
\hline 25 to 29 & 30 & \\
\hline 30 to 34 & 48 & \\
\hline 35 to 39 & 63 & \\
\hline
\end{tabular}




\section{Cureus}

\begin{tabular}{|c|c|c|}
\hline 40 to 44 & \multicolumn{2}{|l|}{79} \\
\hline 45 to 49 & \multicolumn{2}{|l|}{81} \\
\hline 50 to 54 & \multicolumn{2}{|l|}{121} \\
\hline 55 to 59 & \multicolumn{2}{|l|}{110} \\
\hline 60 to 64 & \multicolumn{2}{|l|}{110} \\
\hline 65 to 69 & \multicolumn{2}{|l|}{213} \\
\hline 70 to 74 & \multicolumn{2}{|l|}{145} \\
\hline 75 to 79 & \multicolumn{2}{|l|}{110} \\
\hline 80 to 84 & \multicolumn{2}{|l|}{48} \\
\hline 85 to 89 & \multicolumn{2}{|l|}{28} \\
\hline \multicolumn{3}{|l|}{ Region $^{\ddagger}$} \\
\hline Midwest & $4,724(31 \%)$ & $2,207(33 \%)$ \\
\hline Northeast & $200(1 \%)$ & $170(3 \%)$ \\
\hline South & $8,874(58 \%)$ & $3,498(52 \%)$ \\
\hline West & $1,575(10 \%)$ & $836(12 \%)$ \\
\hline \multicolumn{3}{|l|}{ Service Location $\ddagger$} \\
\hline Physician's Office & $7,228(47 \%)$ & $3,318(49 \%)$ \\
\hline Hospital Inpatient & $655(4 \%)$ & $101(2 \%)$ \\
\hline Hospital Outpatient & $5,273(34 \%)$ & $2,254(34 \%)$ \\
\hline Ambulatory Surgery Center & $219(1 \%)$ & $177(3 \%)$ \\
\hline Other & $1,998(13 \%)$ & $861(13 \%)$ \\
\hline
\end{tabular}

\section{TABLE 3: Characteristics of congenital clubfoot-associated claims}

${ }^{\dagger}$ Do not sum to total because some patient records span multiple age categories.

ҒThese represent the number of claims associated with congenital clubfoot, and percentages are reported relative to the total number of such claims. Percentages may not sum to $100 \%$ due to rounding.

Patients with congenital clubfoot generally received treatment for this condition in either early childhood (up to age four) or late adulthood (age: 65 to 69 years). Of these patients receiving treatment for congenital clubfoot, 1,198 (58\%) were adults at the time of the treatment. Slightly more female (668 [56\%]) than male (530 [44\%]) congenital clubfoot patients received treatment as adults. The vast majority of treatments associated with congenital clubfoot occurred in either the office or outpatient setting for the entire cohort.

Next, the frequencies of mid-tarsal joint, subtalar, ankle, and triple arthrodesis procedures and osteotomies performed in congenital clubfoot patients during adulthood were characterized (Table 4, Figure 2). 


\section{Cureus}

\begin{tabular}{|c|c|c|c|}
\hline Procedure & Total, $\mathbf{n}$ & Male, $n$ & Female, $\mathrm{n}$ \\
\hline Mid-tarsal joint arthrodesis! & 23 & $\mathrm{~N} / \mathrm{A}$ & $\mathrm{N} / \mathrm{A}$ \\
\hline Subtalar arthrodesis & 32 & $11(34 \%)$ & $21(66 \%)$ \\
\hline Ankle arthrodesis & 17 & $\mathrm{~N} / \mathrm{A}$ & $\mathrm{N} / \mathrm{A}$ \\
\hline Triple arthrodesis & 22 & $11(50 \%)$ & $11(50 \%)$ \\
\hline Osteotomy & 62 & $19(31 \%)$ & $43(69 \%)$ \\
\hline
\end{tabular}

\section{TABLE 4: Procedures performed on adults with congenital clubfoot}

†Includes talonavicular arthrodesis. All cells for which occupancy are less than 11 have been suppressed in accordance with regulations.

N/A, not applicable

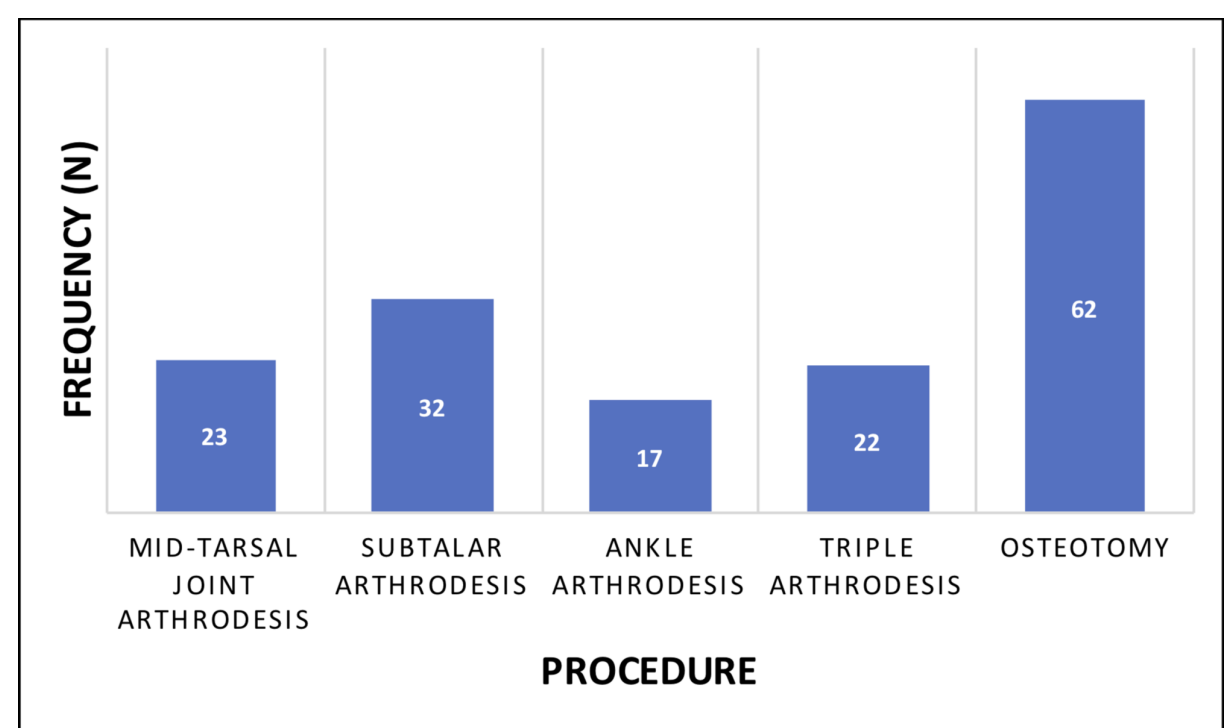

FIGURE 2: Procedures performed on adults with congenital clubfoot

There was an insufficient number of total ankle arthroplasties in this population for further analysis. The majority of adult congenital clubfoot patients (63\%) who underwent mid-tarsal joint, subtalar, ankle, and/or triple arthrodesis procedures did so between the ages of 55 and 74. Similarly, the majority of adult congenital clubfoot patients (52\%) who underwent osteotomy did so between the ages of 55 and 74 . A total of 94 arthrodesis procedures in 73 patients were reported in the database. As 1,198 adult patients in the database received treatment associated with congenital clubfoot, 73/1,198 (6.1\%) of these congenital clubfoot patients who were treated as adults received arthrodesis surgery. Similarly, 62/1,198 (5.2\%) of these congenital clubfoot patients who were treated as adults received osteotomies.

\section{Discussion}

Very few reports exist on the operative treatment of recurrent and residual clubfoot deformities in adults after initial correction during infancy. A thorough review of the literature on congenital clubfoot treatment in adults revealed that arthrodesis was cited in multiple case series, along with osteotomy. To provide further information on surgery in adult clubfoot patients, the population of congenital clubfoot patients who underwent arthrodesis and osteotomy procedures as adults were described using a large administrative claims database covering over 25 million patients. In this database, a subset of adult patients with congenital clubfoot (6.1\%) underwent hindfoot arthrodesis surgery. Future work is needed to better characterize other treatments that are utilized by adult patients with congenital clubfoot and the outcomes for those who undergo ankle or foot surgeries, especially as current evidence is largely limited to case series. For example, the establishment of a longitudinal clubfoot treatment registry to track short- and long-term outcomes, severity, and further treatment or surgeries required in a standardized manner would facilitate more detailed analyses of longitudinal outcomes. Efforts to create similar registries are already ongoing in the joint replacement literature [20]. 


\section{Cureus}

Interestingly, no substantial number of adult clubfoot patients undergoing total ankle arthroplasty could be identified in the database, nor could a case report of total ankle arthroplasty in a clubfoot patient, or a patient with a diagnosis of clubfoot in reports on total ankle arthroplasty, be found in the literature review. This might be attributable to reduced preoperative subtalar mobility, which could result in a higher rate of early loosening after total ankle arthroplasty, or abnormal talar morphology and size precluding total ankle arthroplasty in clubfoot patients [21-22]. However, total ankle arthroplasty has been performed in adult patients with previously-treated congenital clubfoot (Figure 3). Thus, while total ankle arthroplasty may be an operative option for ankle arthritis in adult clubfoot patients, such cases are not yet reported in the literature and the true frequency of such procedures remains unknown. Therefore, future studies are needed to describe the efficacy and outcomes of total ankle arthroplasty performed on adult clubfoot patients.
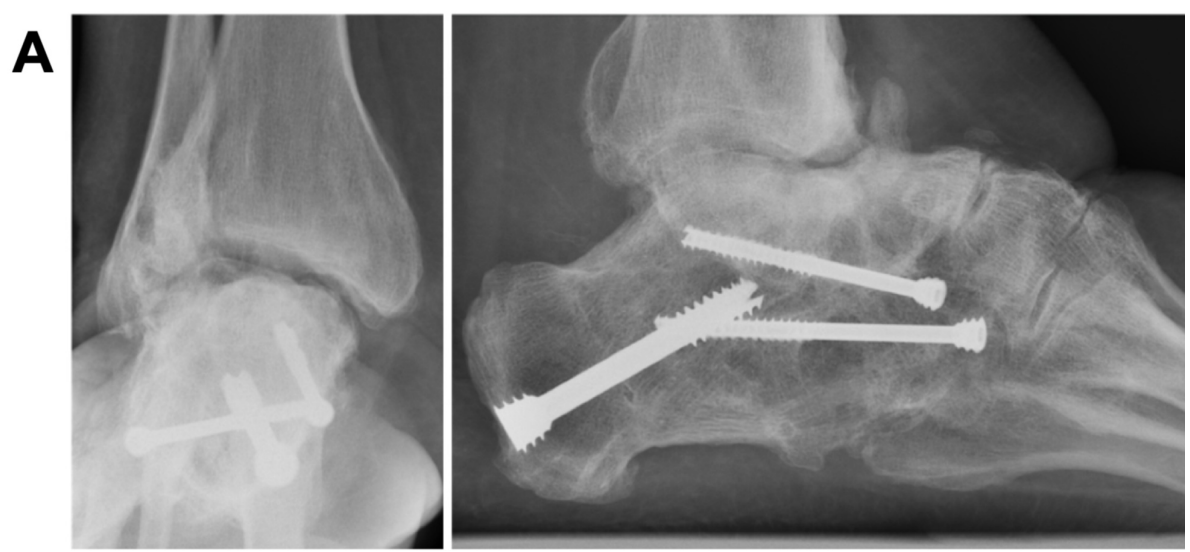

B
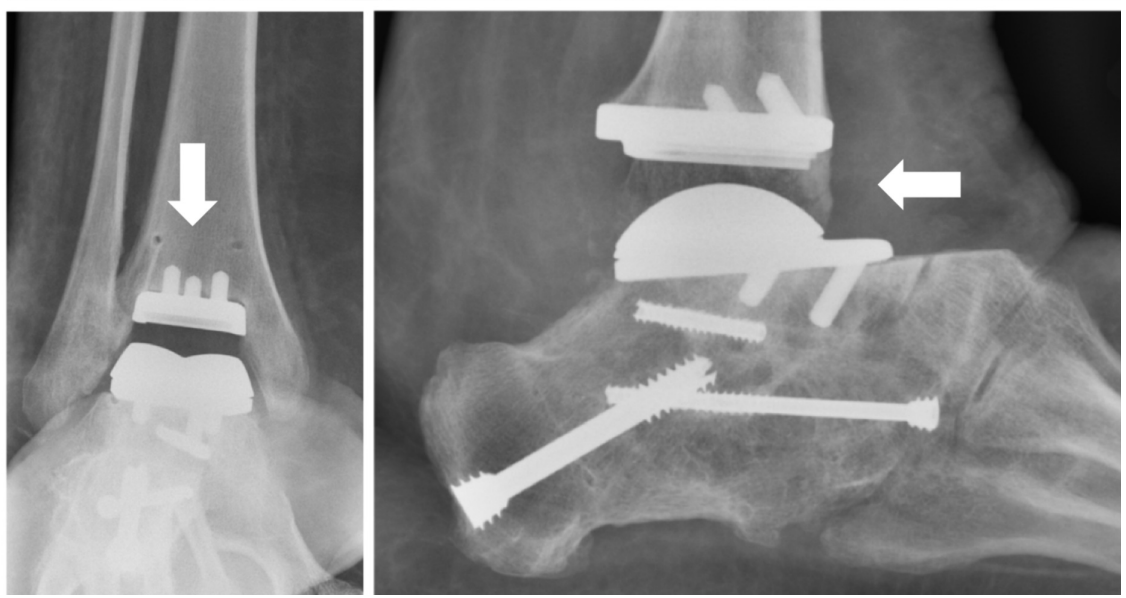

FIGURE 3: A) Preoperative and B) postoperative anteroposterior and lateral radiographs of an adult patient with previously operated clubfoot with ankle arthritis who underwent total ankle arthroplasty

Ankle arthroplasty procedures (arrows) are being performed in adult clubfoot patients but are not yet reported in the literature.

Case courtesy of Jeremy McCormick, MD, St. Louis, MO

Although the database contained 1,198 adult patients with congenital clubfoot, $94 \%$ of these patients did not undergo mid-tarsal joint arthrodesis, subtalar arthrodesis, ankle arthrodesis, triple ankle arthrodesis, total ankle arthroplasty, or osteotomies for the treatment of this condition as adults (Table 3). While likely uncommon as evidenced by our literature review, some of these patients may have undergone soft tissue procedures and thus were missed by our database analysis. Nevertheless, it remains unknown whether viable non-operative treatment modalities or surgical alternatives to hindfoot arthrodesis exist for these patients. Further outcomes research using longitudinal data is needed to answer this question.

These results should be viewed in light of the limitations. The inherent limitations of database research, including a lack of precision with coding schemes, have been reviewed elsewhere [12]. Although the database comprises the representation of all U.S. states and diverse medical and surgical specialties, it is limited due to being from a single insurer with a market share that likely differs by geographic region and thus may not be representative of the national adult clubfoot population. This may limit external generalizability. Moreover, our data only captures insured populations, with few Medicaid and no uninsured 
patients represented, which further limits generalizability. Further, with a prevalence of one in 1,000 live births, approximately 25,000 cases of congenital clubfoot would be expected in the database of over 25 million members. Instead, only 2,056 patients with congenital clubfoot were identified even though all diagnostic fields were queried [1]. This suggests that patients with congenital clubfoot do not commonly seek treatment related to this condition after a certain age (i.e. after age 14) and were missed by our analysis. The bimodal distribution of age within the clubfoot claims data is consistent with this interpretation (Table 3). Other explanations include inaccurate, incomplete, or incorrect medical coding, or that adult clubfoot patients are ultimately diagnosed with ankle or foot arthritis and coded as such without including the clubfoot code. Thus, the denominators within this study (e.g. total congenital clubfoot patients in the database) should be interpreted with caution. In other words, although this study demonstrates the frequency of arthrodesis and osteotomy procedures in adult clubfoot patients, the percentage of clubfoot patients treated as children who require further surgery as adults remains uncertain.

In addition, although the prevalence of congenital clubfoot is at least twice as high in males compared to females, we found that slightly more female than male clubfoot patients received treatment as adults [23]. We cannot exclude systematic differences between the clubfoot population in our database and the overall clubfoot population, especially since there is only a slight male clubfoot predominance in the entire database when children are included. However, because claims databases only capture patients who are treated, it is also possible that females are more likely to seek treatment for clubfoot as adults, perhaps due to sex-specific differences in severity and/or risk of recurrent or residual clubfoot. Notably, a recent study in infants found no difference in clubfoot severity due to sex [24]. Nevertheless, because claims databases cannot capture clubfoot severity, studies with longer-term follow-up to evaluate sex-based differences in previously-treated adult clubfoot patients are warranted.

Also, the possibility that these procedures were not performed to treat congenital clubfoot but rather for unrelated, co-morbid lower extremity conditions cannot be excluded in the database analysis. Nevertheless, the literature search showed that most surgeries performed in adult clubfoot patients were due to osteoarthritis or other degenerative changes. There is additional evidence for higher rates of osteoarthritis in adult patients treated for clubfoot in childhood. For example, a prospective study on children with unilateral clubfoot treated before the age of two and followed for 13 to 24 years showed that osteoarthritis was more severe in clubfeet than in contralateral non-clubfeet [25]. Other studies have reported arthritis, along with varus and valgus deformities and degeneration of the foot and ankle, as medical problems that patients treated for clubfoot in childhood have as adults $[2,17,26]$. While discussing treatment options for adult clubfoot patients, Walling stated that triple arthrodesis is the only option for stiffness and arthritis at joints following clubfoot surgery during childhood [19]. Finally, it is known that operative treatment of clubfoot in childhood, such as extensive soft tissue release, can result in several complications including osteoarthritis, often presenting as painful and stiff feet [25,27].

Finally, the clinical care of clubfoot in infants and children has changed in the past few decades, and the database analysis cannot provide information on how the patients were previously treated in childhood (i.e. nonoperatively or operatively). Thus, the question of whether successful nonoperative correction leads to a lower rate of adult ankle or foot surgery cannot be answered by the analysis of this dataset. Additionally, although the Ponseti method is currently the gold standard of care for the treatment of congenital clubfoot, some children today still receive other treatments for clubfoot and there are adult patients who were treated with other techniques as children who now have pain and/or residual deformity. Thus, it was important to elucidate the surgeries that are being performed on adults who received non-Ponseti treatments as children and now require further treatment. Future studies are warranted to explore the epidemiology, severity, and treatment methods for clubfoot in children (including the Ponseti method), following these patients through adulthood to document ankle and foot function and rates of subsequent surgery.

\section{Conclusions}

Despite the prevalence of congenital clubfoot as a birth defect of the lower limb, little information exists on operative procedures utilized in adults with previously-treated congenital clubfoot. In this report, an extensive literature review of the operative treatments used in adults with previously-treated congenital clubfoot revealed that hindfoot arthrodesis and osteotomy have been reported in this population. This study then characterized the frequency at which adult congenital clubfoot patients underwent mid-tarsal joint arthrodesis, subtalar arthrodesis, ankle arthrodesis, triple arthrodesis, and osteotomy in a large, administrative claims database.

\section{Appendices}

The following search strings were used in the PubMed and Embase databases, respectively.

I. (("Clubfoot/drug therapy"[Mesh] OR "Clubfoot/surgery"[Mesh] OR

"Clubfoot/therapy"Mesh]) OR ((clubfoot[Mesh] OR clubfoot[tw]) AND (((ankle[tw] OR subtalar[tw] OR talonavicular[tw] OR tarsal[tw] OR tarsus[tw]) AND (fuse[tw] OR fusion[tw] OR fusing[tw] OR arthrodesis[tw] OR replacement[tw] OR arthroplasty[tw])) OR "triple arthrodesis"[tw] OR (osteotomy[tw] AND (calcaneal[tw] OR midfoot[tw] OR "first metatarsal"[tw])) OR talectomy[tw])) OR ("surgery" [Subheading] AND 
clubfoot[Mesh])) AND (adult[Mesh] OR adult[tw])

II. ((('ankle fusion':ti,ab,kw OR 'subtalar fusion':ti,ab,kw OR 'talonavicular fusion':ti,ab,kw OR 'triple arthrodesis':ti,ab,kw OR talectomy:ti,ab,kw OR 'first metatarsal osteotomy':ti,ab,kw OR 'midfoot osteotomy':ti,ab,kw OR 'calcaneal osteotomy':ti,ab,kw OR 'subtalar arthrodesis'/exp OR 'subtalar arthrodesis':ti,ab,kw OR 'ankle arthroplasty'/exp OR 'ankle arthroplasty':ti,ab,kw OR 'ankle arthrodesis'/exp OR 'ankle arthrodesis':ti,ab,kw OR 'ankle replacement'/exp OR 'ankle replacement':ti,ab,kw) AND ('clubfoot'/exp AND 'clubfoot':ti,ab,kw)) OR (('clubfoot'/exp AND 'clubfoot':ti,ab,kw) AND ('drug therapy'/lnk OR 'surgery'/lnk OR 'therapy'/lnk))) AND (adult OR 'adult'/exp)

\section{Additional Information \\ Disclosures}

Human subjects: All authors have confirmed that this study did not involve human participants or tissue. Animal subjects: All authors have confirmed that this study did not involve animal subjects or tissue. Conflicts of interest: In compliance with the ICMJE uniform disclosure form, all authors declare the following: Payment/services info: All authors have declared that no financial support was received from any organization for the submitted work. Financial relationships: All authors have declared that they have no financial relationships at present or within the previous three years with any organizations that might have an interest in the submitted work. Other relationships: All authors have declared that there are no other relationships or activities that could appear to have influenced the submitted work.

\section{Acknowledgements}

The authors thank Connie Wong for her expert guidance during the literature review.

\section{References}

1. Parker SE, Mai CT, Strickland MJ, et al.: Multistate study of the epidemiology of clubfoot . Birt Defects Res A Clin Mol Teratol. 2009, 85:897-904.

2. Ramseier LE, Ramseier LE, Schoeniger R, et al.: Treatment of late recurring idiopathic clubfoot deformity in adults. Acta Orthop Belg. 2007, 73:641-647.

3. Sobel E, Giorgini R, Velez Z: Surgical correction of adult neglected clubfoot: three case histories. J Foot Ankle Surg. 1996, 35:27-38. https://doi.org/10.1016/S1067-2516(96)80009-3

4. Mossad El-Tayeby H: The neglected clubfoot: a salvage procedure . J Foot Ankle Surg. 1998, 37:501-509.

5. Vienne P, Ramseier L, Schoeniger R, et al.: Double arthrodesis for the treatment of late recurrence of clubfoot in adulthood. J Bone Joint Surg Br. 2008, 90-B:274.

6. Fang X, Brown DS, Florence CS, Mercy JA: The economic burden of child maltreatment in the United States and implications for prevention. Child Abuse Negl. 2012, 36:156-165.

7. Peterson C, Florence C, Klevens J: The economic burden of child maltreatment in the United States, 2015. Child Abuse Negl. 2018, 86:178-183.

8. Donn SM, Chiswick ML, Fanaroff JM: Medico-legal implications of hypoxic-ischemic birth injury. Interface Perinatol Ethics Law. 2014, 19:317-321.

9. Mello MM, Rimm EB, Studdert DM: The McLawsuit: the fast-food industry and legal accountability for obesity. Health Aff (Millwood). 2003, 22:207-216.

10. Finkelstein EA, Graham WCK, Malhotra R: Lifetime direct medical costs of childhood obesity. Pediatrics. 2014, 133:854-10.

11. Cawley J: The economics of childhood obesity. Health Aff (Millwood). 2010, 29:364-371.

12. Pugely AJ, Martin CT, Harwood J, et al.: Database and Registry Research in Orthopaedic Surgery: Part I Claims-Based Data. J Bone Joint Surg Am. 2015, 97:1278-1287.

13. Blitz NM, Hoyal R, Lee T: Interposition of the flexor hallucis longus tendon through the subtalar joint as a late complication of pediatric clubfoot repair: a case report. J Foot Ankle Surg. 2008, 47:321-325.

14. Eberhardt O, Wachowsky M, Wirth T, Fernandez Fernandez F: Limitation of flatfoot surgery in overcorrected clubfeet after extensive surgery. Arch Orthop Trauma Surg. 2018, 138:1037-1043.

15. Wei SY, Sullivan RJ, Davidson RS: Talo-navicular arthrodesis for residual midfoot deformities of a previously corrected clubfoot. Foot Ankle Int. 2000, 21:482-485.

16. Andjelkov K, Llull R, Colic M, et al.: Aesthetic improvement of undeveloped calves after treatment of congenital clubfoot deformity. Aesthet Surg J. 2018, 38:1200-1209.

17. Knupp M, Barg A, Bolliger L, Hintermann B: Reconstructive surgery for overcorrected clubfoot in adults. J Bone Joint Surg Am. 2012, 94:e110. 10.2106/JBJS.K.00538

18. Majeed H, Deall C, Mann A, McBride DJ: Multiple intratendinous ossified deposits of the Achilles tendon: case report of an unusual pattern of ossification. Foot Ankle Surg. 2015, 21:e33-e35.

19. Walling AK: The adult clubfoot (congenital pes cavus). Foot Ankle Clin. 2008, 13:307-314.

20. Ayers DC, Franklin PD: Joint replacement registries in the United States: a new paradigm . J Bone Joint Surg Am. 2014, 96:1567-1569.

21. Guyer AJ, Richardson EG: Current concepts review: total ankle arthroplasty. Foot Ankle Int. 2008, 29:256264.

22. Doets HC, Brand R, Nelissen RGHH: Total ankle arthroplasty in inflammatory joint disease with use of two mobile-bearing designs. J Bone Joint Surg Am. 2006, 88:1272-1284. 10.2106/JBJS.E.00414

23. Miedzybrodzka Z: Congenital talipes equinovarus (clubfoot): a disorder of the foot but not the hand . J Anat. 2003, 202:37-42.

24. Zionts LE, Jew MH, Ebramzadeh E, Sangiorgio SN: The influence of sex and laterality on clubfoot severity . J 


\section{Cureus}

Pediatr Orthop. 2017, 37:129-133. 10.1097/BPO.0000000000000603

25. van Gelder JH, van Ruiten AGP, Visser JD, Maathuis PGM: Long-term results of the posteromedial release in the treatment of idiopathic clubfoot. J Pediatr Orthop. 2010, 30:700-704. 10.1097/BPO.0b013e3181ec9402

26. Brodsky JW: The adult sequelae of treated congenital clubfoot . Foot Ankle Clin. 2010, 15:287-296.

27. Dobbs MB, Nunley R, Schoenecker PL: Long-term follow-up of patients with clubfeet treated with extensive soft-tissue release. J Bone Joint Surg Am. 2006, 88:986-996. 10.2106/JBJS.E.00114 